Works of the Faculty of Forestry

University of Sarajevo

No. 1, 2019 (1-19)

UDK $630 * 232: 582.475(497.6)$

\title{
VARIATION IN GROWTH AMONG NINE BOSNIAN HERZEGOVINIAN PROVENANCES OF SILVER FIR (Abies alba Mill)
}

Varijabilnost u rastu devet bosanskohercegovačkih provenijencija jele (Abies alba Mill.)

\author{
Ćemal Višnjić ${ }^{1}$, Besim Balić ${ }^{1}$, Velid Halilović ${ }^{1}$, Fuad Šehić
}

\begin{abstract}
Provenance experiments with forest trees provide valuable information about the growth and adaptability of population, often transferred from remote geographical regions and various climate conditions. This study researches the growth of nine provenances of silver fir from the area of its natural distribution in Bosnia and Herzegovina. The experiment was established in the year 1991 in the form of a random block system with 5 repetitions. For planting, we used five-year-old seedlings (2/3), and planting spacing was $2 \times 2 \mathrm{~m}$. Each Silver fir provenance was included with 320 plants. Measurement results in the $28^{\text {th }}$ year of age show the existence of variations between silver fir provenances in characteristics; mean height, mean diameter and average tree volume. Silver fir provenance from Bosanski Petrovac showed the best results. The mean height of this Silver fir provenance at the age of 28 was $9.1 \mathrm{~m}$, while the mean diameter was $11.9 \mathrm{~cm}$. Provenances that show the lowest growth $(8.1 \mathrm{~m})$ were from Pale, Olovo-Klis and Konjic. Silver fir provenance from Konjic has the lowest mean diameter $(10.7 \mathrm{~cm})$. In all provenances, we have had a culmination of height increment in age between 20 and 25 years. Variation between tested silver fir provenances for examined characteristic "mean height" was larger (four groups of population) compared to examined characteristic "mean diameter" (two groups of population). Volume of mean tree $\left(0.062 \mathrm{~m}^{3}\right)$ and assortment $\left(111.33 \mathrm{~m}^{3} / \mathrm{ha}\right)$ in Bosanski Petrovac provenance was larger than spreadsheet values for the first yield class for Central Europe conditions. The trial shows that silver fir in Bosnia and Herzegovina is variable on the local level due to specific micro-habitual conditions in which it grows.
\end{abstract}

Key words: provenances, fir, silviculture, morphological characteristics

\section{INTRODUCTION - Uvod}

Silver fir (Abies alba Mill.) is one of the ecologically most important and economically most productive tree species. Due to its shade tolerance, adaptability to exposure and ability to coexist with other species, it is fundamental species for

\footnotetext{
${ }^{1}$ Faculty of Forestry, University of Sarajevo, Zagrebačka 20, 71000 Sarajevo, Bosnia and Herzegovina

${ }^{2} \mathrm{PE}$ „S̆PD ZDK“ Itd Zavidovići, Alije Izetbegovića 25, 72220 Zavidovići, Bosnia and Herzegovina, PU „Šumarija“ Olovo
} 
preservation of forest ecosystem biodiversity (KERR, 2015, DOBROWOLSKA et al. 2017). According to STEFANOVIĆ, (1977) in Bosnia and Herzegovina, silver fir is in the whole spectre of forest communities. It can be found in all climate-edaphic zones, and ait builds our economically most significant mixed forests with beech and spruce. According to available data, silver fir spreads over clean or mixed assortments with beech and spruce on the area of 722,000 hectares which makes $40 \%$ of the total area of high economic forests. Fir growing stock in B\&H is estimated to $66,000,000 \mathrm{~m}^{3}$ or $15 \%$ of the total growing stock of high economic forests. Areal of silver fir in Bosnia and Herzegovina is in the area of Dinarides with a more humid climate.

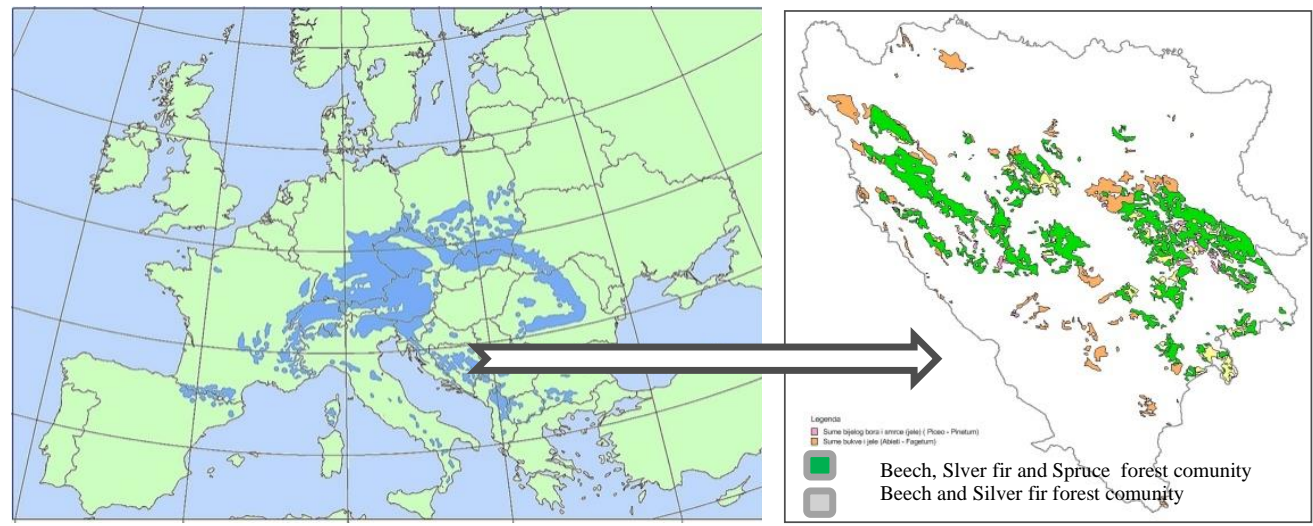

Figure 1. Areal of silver fir in Europe (Euforgen, Wolf, 2003), and Bosnia and Herzegovina (Stefanović and others, 1983)

Slika 1. Areal jele u Evropi (Euforgen, Wolf, 2003), i Bosni i Hercegovini (Stefanović i dr., 1983)

It appears on altitudes of 400-1500 (1600) $\mathrm{m}$, grows in its natural enclaves on the border towards the Pannonian pool (Kozara). Local factors like orography, exposition and soil, can contribute to significant modifications of climate and therefore impact on expansion, narrowing, exclusion or interruption of vertical or horizontal distribution of fir (PINTARIĆ, 2002).

In the past 200 years, a natural area of silver fir reduced significantly (WOLF, 2003). Reduction of silver fir areal is mostly a consequence of stress caused by natural factors and inadequate management systems (BARBU, 1991, BADEA et al. 2004, ELLING et al. 1999, FILIPIAK and NAPIERALA-FILIPIAK 2009, UŠČUPLIĆ, 1992, UŠČUPLIĆ et al. 2007, WENTZEL, 1980, WOLF, 2003). Results of up-to-date research shows that basic reason for degradation of silver fir is air and soil pollution by industrial contamination, that has damaging effect on the silver fir, but also on other tree species (ELLING, 1993, MEKIĆ, 1988, LARSEN and FRIDRICH, 1988, MEKIĆ and LARSEN 1991, DUCCI, 1991, HALILOVIĆ et al. 2009a, 2009b, 2013, BALLIAN and HALILOVIĆ, 2016). 
In the middle of the past century, intensive works started on the improvement of ecological conditions in habitats of silver fir, i.e. optimization of mixing of tree species, natural revitalization and preservation of closed-canopy density of mixed assortments that are favorable to the silver fir (UŠČUPLIĆ, 1992). As stated by MEKIĆ, (1992) on of long-term objectives is finding and selection of tolerant provenances and individual firs that could endure pollution. Besides that, it is necessary to work on hybridization within species with resilient provenances that showed tolerance to pollutants such as sulfur dioxide and fluorine (LARSEN, 1986, LARSEN and FRIDRICH 1988, MEKIĆ, 1988, MEKIĆ and LARSEN 1991), and hybridizations with other fir species from North America and Asia (KOBLIHA et al. 2013a and b, 2014, KORMUTAK et al. 2013).

The first trial with silver fir provenances was set-up in Switzerland at the beginning of the last century (ENGLER, 1905) and was focused on the research of individual growth of trees. BECKER, (1971) in his research with different fir provenances pointed out that the growth of fir is genetically conditioned and is different as per geographic regions. Examination of geographic variability of silver fir considering the dynamics of increment was conducted by LARSEN, (1986). The best growth was present in Calabrian provenance, while provenances from Western and Central Europe were worse, with much smaller variability within the population. Provenances from South-East Europe have had significant differences in increment one to another, and also comparing to Carpathian provenances. MEKIĆ, (1988) determined the existence of large variability of Calabrian provenances in terms of morphological and physiological indicators. Similar results reached DUCCI, 1991 showed significant variability of silver fir, within-population and between populations, from Central and Southern Italy. In trials in England, with 33 provenances of silver fir from whole Europe, the best growth was of the provenance from Calabria, worst growth was from French provenances, including Normandy, which has a climate similar to the one of England (KAJBA, 2001, KERR, 2015).

This study researches variability in growth among nine Bosnian-Herzegovinian provenances of silver fir. Measurements were conducted on 28-year old fir trees planted on plots on location Delimusa near Olovo (Central Bosnia).

\section{MATERIAL AND METHODS - Materijal i metode}

Experiment with nine Bosnian-Herzegovinian provenances of silver for was established on location "Delimusa" near Olovo in Central B\&H. The experimental plot is located in the area of beech and fir forests with spruce an altitude of $970 \mathrm{~m}$, exposed towards the north with the slope of terrain between 10 and $20 \%$. Soil belongs to the type of deep brown soils (distric cambisol) on volcanic and sediment rocks.

Seeds for the trial have the origin from nine locations in Bosnia and Herzegovina (Bugojno, Bosanski Petrovac, Olovo-Palež, Pale, Konjic, Fojnica, Sokolac, Olovo-Klis and Prozor), from the position of altitude between $850 \mathrm{~m}$ and $1.300 \mathrm{~m}$. The most western 
provenance comes from Bosanski Petrovac, while the most southern comes from the Herzegovina area-Konjic. Geographic distribution of the source populations and their ecological - vegetation origin are provided in Figure 2.

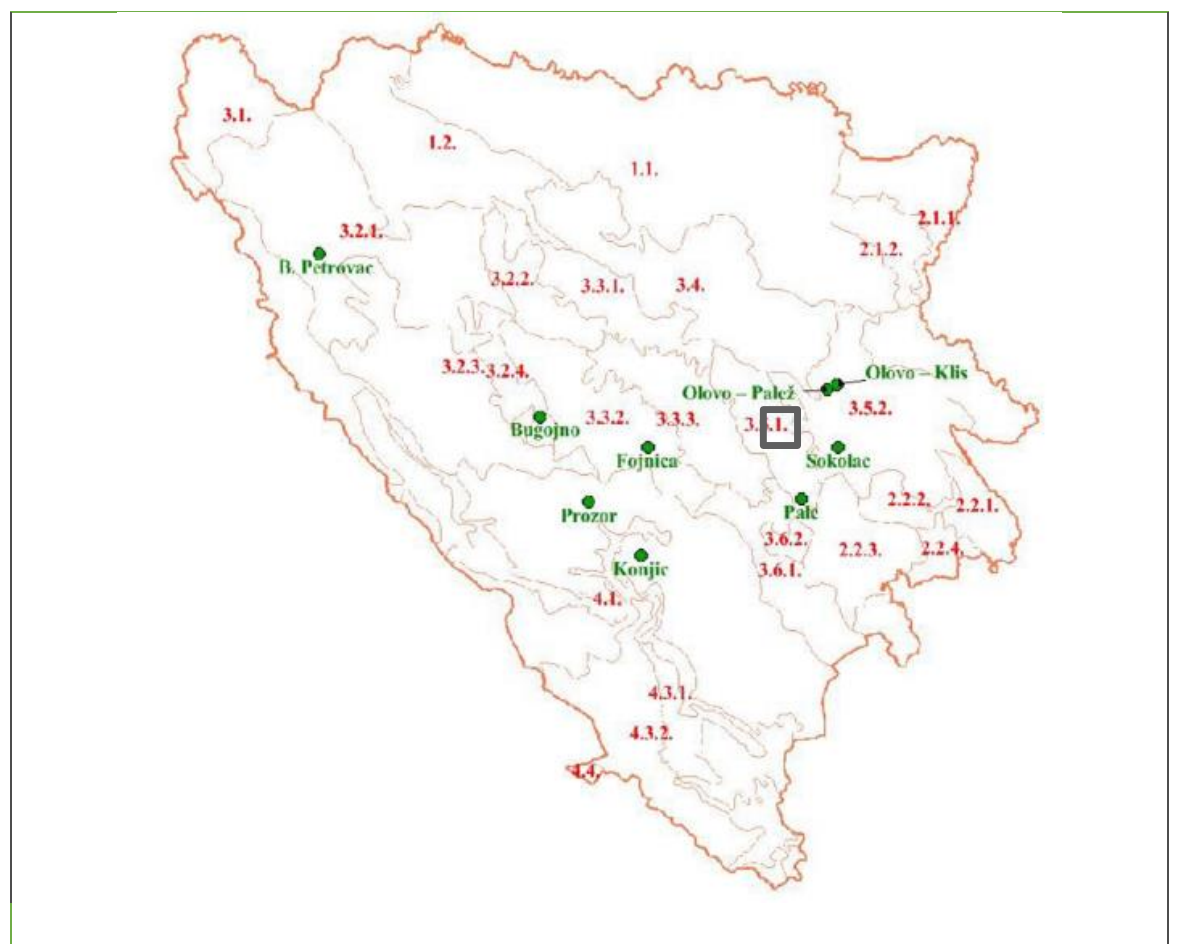

Figure 2. Origin of the seeds used for the provenance test as per ecological-vegetation areas Karta 2. Porijeklo sjemena koje je korišteno za test provenijencija po ekološko-vegetacijskim područjima

$\square$ Delimusa -Location with experimental plot/area

Delimusa - Lokalitet sa eksperimentalnom površinom

Overview and main orographic - edaphic characteristics of original assortments of fir from which we gathered seeds for the provenance test are provided in Table 1. 
Table 1. Main ecological - habitat characteristics of assortments from which the seeds were collected for fir provenance test on location "Delimusa" near Olovo

Tabela 1. Osnovne ekološko-stanišne karakteristike sastojina sa kojih je prikupljano sjeme za test provenijencija jele na lokalitetu "Delimusa” kod Olova

\begin{tabular}{|c|c|c|c|c|c|c|}
\hline No & Provenance & Soil type & Geological- petrographic & Altitude (m) & Ex. & $\begin{array}{c}\text { Slope of terrain } \\
(\%)\end{array}$ \\
\hline 1. & Sokolac & $\begin{array}{l}\text { calcocambisol, } \\
\text { calcomelanosol }\end{array}$ & Limestone & 940 & $S-W$ & 13 \\
\hline 2. & Prozor & calcomelanosol, luvisol & Limestone moraine & 1,300 & $N-E$ & $5-10$ \\
\hline 3. & B. Petrovac & $\begin{array}{c}\text { rendzina, } \\
\text { calcocambisolpseudogle }\end{array}$ & Dolomite & 900 & $\mathrm{~N}$ & 2 \\
\hline 4. & Fojnica & districcambisol & Rhyolite & 1,010 & - & - \\
\hline 5. & Olovo - Palež & calcocambisol, luvisol & Limestone & 960 & $\mathrm{~N}-\mathrm{E}$ & 12 \\
\hline 6. & Olovo - Klis & calcocambisol, luvisol & Limestone & 850 & $\mathrm{~N}-\mathrm{W}$ & 13 \\
\hline 7. & Bugojno & rendzina, calcocambisol & Dolomite and limestone & 1,090 & $\mathrm{~N}-\mathrm{W}$ & $10-25$ \\
\hline 8. & Konjic & $\begin{array}{l}\text { calcocambisol, } \\
\text { calcomelanosol }\end{array}$ & Firm limestone & 1,030 & $\mathrm{E}-\mathrm{EN}$ & $10-22$ \\
\hline 9. & Pale & $\begin{array}{l}\text { districcambisol, } \\
\text { calcomelanosol }\end{array}$ & $\begin{array}{c}\text { Verfene schist, } \\
\text { sandstone, limestone }\end{array}$ & 1,200 & $\mathrm{~N}-\mathrm{E}$ & 20 \\
\hline
\end{tabular}

The experiment was established in a form of random block system with five repetitions (five belts). Each of five belts is separated into ten small plots of square shape in dimensions of 14 x 14 meters. Within plots, we planted 5-year old silver fir seedlings (2/3), with planting spacing of $2 \times 2$ meters. On each of the plots we planted 64 seedlings, so the number of seedlings planted per one provenance was 320 (64 x 5 blocks). On the whole experimental plot/area we planted 2,880 seedlings (9 provenances $\mathrm{x} 320$ seedlings).

Table 2. Design of the experiment with nine provenances of fir - random block system Tabela 2. Dizajn eksperimenta sa devet provenijencija jele -slučajni blok sistem

\begin{tabular}{|c|c|c|c|c|c|c|c|c|c|}
\hline Bugojno & Ol. Klis & Ol. Palež & Fojnica & Prozor & B. Petrovac & Sokolac & Pale & Konjic & Control \\
\hline B. Petrovac & Sokolac & Pale & Konjic & Control & Bugojno & Ol. Klis & O1. Palež & Fojnica & Prozor \\
\hline Control & Bugojno & Ol. Klis & Ol. Palež & Fojnica & Prozor & Konjic & Sokolac & Pale & B. Petrovac \\
\hline Fojnica & Prozor & B. Petrovac & Sokolac & Konjic & Pale & Control & Bugojno & Ol. Klis & Ol. Palež \\
\hline Pale & Konjic & Control & Bugojno & Ol. Klis & Ol.Palež & Fojnica & B. Petrovac & Prozor & Sokolac \\
\hline
\end{tabular}


Measurements on experimental plot/area were done on the 28-year old age of trees. On all live trees we determined breast height diameter $(1.30 \mathrm{~m})$, with millimetercaliper in a cross manner, with accuracy up to $1 \mathrm{~mm}$, and height of all trees in meters $( \pm 10 \mathrm{~cm})$.

From each provenance we further extracted 5 trees each, representatives of provenance per mean diameter and mean height (5 x $9=45$ trees). On treesrepresentatives we performed dendrometric analysis of trees in software application "DAS-v1" (BALIĆ and MEŠKOVIĆ, 2012).

For each tree on the experimental plot, we calculated the volume. Volume was calculated as per the regression model (NAGEL, 1988), as follows:

$\mathrm{V} 0=\exp (\mathrm{a} * \ln (\mathrm{d})+\mathrm{b} * \ln (\mathrm{h}-1.3)+\mathrm{c})$

where:

$\mathrm{d}$ - breast height diameter on the distance of $1.30 \mathrm{~m}$ from the ground

$\mathrm{h}-$ tree height

$\mathrm{a}, \mathrm{b}, \mathrm{c}-$ parameters of the function; $\mathrm{a}=1.86089, \mathrm{~b}=0.85685, \mathrm{c}=-9.31895$

\section{RESULTS - Rezultati}

\section{Mean tree diameter}

Research results for characteristic "mean diameter" are shown in Table 3. From the table, it is visible that the highest mean diameter is in the provenance Bosanski Petrovac. In this provenance in 28-years of age, we recorded a mean breast height diameter of $11.9 \mathrm{~cm}$. Somewhat smaller diameters we recorded in provenances Fojnica $(11.2 \mathrm{~cm})$, Sokolac and Olovo-Klis $(11.1 \mathrm{~cm})$. The smallest mean diameters were recorded in provenances Konjic $(10.7 \mathrm{~cm})$, Olovo-Palež, Bugojno and Pale $(10.8 \mathrm{~cm})$.

Table 3: Mean diameters for fir provenances in 28-years of age on experimental area Delimusa Tabela 3: Srednji prečnik provenijencija jele u 28. godini starosti na oglednoj površini Delimusa

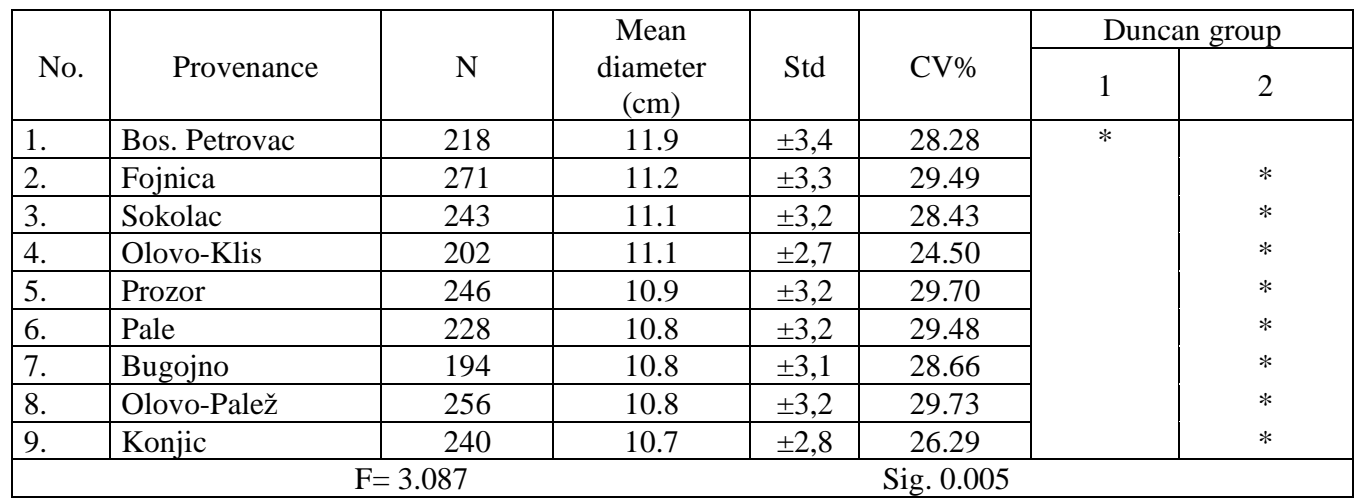


Analysis of variance determines that there is a statistically significant difference in the examined characteristic "mean breast height diameter" between tested provenances on the level of significance of $95 \%$. Duncan test determines the grouping of silver fir provenances, in terms of mean diameter of trees of tested provenances, into two Duncan groups. The first group, with the largest breast height diameter, includes provenance Bosanski Petrovac, while the second group, with smaller diameter, includes all other fir provenances. Based on the results of the conducted test it is visible that there is no grouping of provenances in terms of mean diameter per ecological production zones, areas and regions in B\&H conducted by STEFANOVIĆ et al., (1983). However, provenance Bosanski Petrovac which is geographically most distant related to the location where experiment with fir provenances was set, shows the best results in terms of mean diameter, while one of the local provenances Olovo-Palež has the lowest values of mean diameter.The coefficient of variability $(\mathrm{CV} \%)$ of the mean diameter in all provenances is in a range up to $30 \%$.

\section{Mean tree height}

Measurement results for tree heights of 9 provenances of silver fir are presented in Table 4. From the table, it is visible that the highest mean height is in the provenance Bosanski Petrovac $(9.1 \mathrm{~m})$. Somewhat smaller values of mean height are shown by provenances Sokolac $(8.7 \mathrm{~m})$ and Fojnica $(8.6 \mathrm{~m})$. Then follows provenances Prozor $(8.3 \mathrm{~m})$ and provenances Olovo-Palež and Bugojno with $8.2 \mathrm{~m}$. Provenances with the lowest mean height are Olovo-Klis, Konjic and Pale $(8.1 \mathrm{~m})$. Analysis of variance shown that there are statistically significant differences in the level of statistical significance of $95 \%$ for examined characteristic mean height. Results of the Duncan test show grouping of fir provenances in terms of mean height into 4 Duncan groups. The first group, characterized by highest mean height of fir trees, includes provenance Bosanski Petrovac, and the second group, with some lower mean height, includes provenances Sokolac and Fojnica, the third group includes provenances Prozor, OlovoPalež and Bugojno and the fourth Duncan group with the lowest value of mean height, includes provenances Olovo-Klis, Konjic and Pale. 
Table 4. Mean height of 9 provenances of fir in 28-years of age on experiment area Delimusa Tabela 4. Srednja visina 9 provenijencija jele u 28. godini starosti na eksperimentu Delimusa

\begin{tabular}{|c|c|c|c|c|c|c|c|c|c|}
\hline \multirow[b]{2}{*}{ No. } & \multirow[b]{2}{*}{ Provenance } & \multirow[b]{2}{*}{$\mathrm{N}$} & \multirow{2}{*}{$\begin{array}{l}\text { Mean } \\
\text { height } \\
(\mathrm{cm})\end{array}$} & \multirow[b]{2}{*}{ Std } & \multirow[b]{2}{*}{$\mathrm{CV} \%$} & \multicolumn{4}{|c|}{ Duncan group } \\
\hline & & & & & & 1 & 2 & 3 & 4 \\
\hline 1. & Bos. Petrovac & 218 & 9.1 & \pm 2.6 & 28.89 & \multirow[t]{9}{*}{$*$} & \multirow{9}{*}{$\begin{array}{l}* \\
* \\
* \\
*\end{array}$} & \multirow{9}{*}{$\begin{array}{l}* \\
* \\
* \\
*\end{array}$} & \multirow{9}{*}{$\begin{array}{l}* \\
* \\
* \\
* \\
*\end{array}$} \\
\hline 2. & Sokolac & 243 & 8.7 & \pm 2.2 & 25.00 & & & & \\
\hline 3. & Fojnica & 271 & 8.6 & \pm 1.9 & 22.09 & & & & \\
\hline 4. & Prozor & 246 & 8.3 & \pm 1.9 & 22.32 & & & & \\
\hline 5. & Olovo-Palež & 256 & 8.2 & \pm 2.0 & 24.57 & & & & \\
\hline 6. & Bugojno & 194 & 8.2 & \pm 2.0 & 24.06 & & & & \\
\hline 7. & Olovo-Klis & 202 & 8.1 & \pm 1.3 & 16.50 & & & & \\
\hline 8. & Konjic & 240 & 8.1 & \pm 1.6 & 20.25 & & & & \\
\hline 9. & Pale & 228 & 8.1 & \pm 1.9 & 23.09 & & & & \\
\hline \multicolumn{3}{|r|}{$\mathrm{F}=6.125$} & \multicolumn{7}{|c|}{ Sig. 0.005} \\
\hline
\end{tabular}

Having in mind gained grouping of fir provenances in terms of mean tree height, we cannot notice the link of this characteristic with the origin of provenances to individual areas defined by ecological - production regionalization. However, we notice certain grouping of provenances based on geographic position. The most western provenance Bosanski Petrovac that makes a separate group has the highest mean height, while provenances with the lowest mean height, Olovo-Klis, Konjic and Pale in geographic sense are located in south-east part of B\&H. The coefficient of variability $(\mathrm{CV} \%)$ of examined characteristics is in range up to $29 \%$.

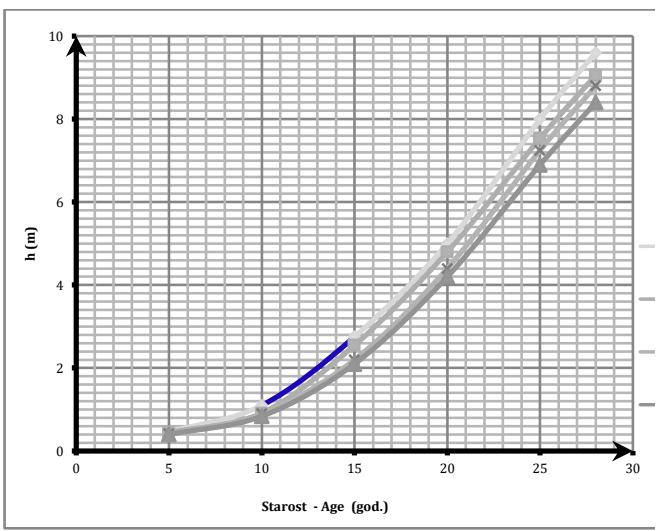

Graph 1. Growth of height of representatives of four provenance groups

Grafikon 1. Razvoj visine predstavnika 4 grupe provenijencija

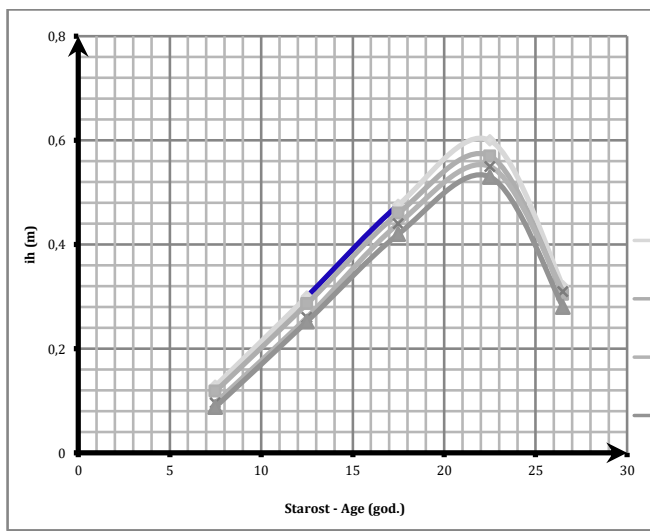

Graph 2. Increment in height of representatives of four provenance groups Grafikon 2. Prirast u visinu predstavnika 4 grupe provenijencija 
Analysis of growth and increment in height of fir provenances was done for representatives of 4 (four) provenance groups which between themselves are statistically significantly different in growth in height (see Table 4. Duncan test). Graph 1 shows the curve of growth in height for four fir provenance groups. From the Graph, it is visible that during the set-up of experiment plants of different fir provenances have had approximately the same height (for planting used seedlings 5-years old). In further phases of growth appeared differentiation in height. From the Graph is visible that provenance Bosanski Petrovac, which is in the first group, from the start (5 years of age) shows the best growth, but it gets clearly isolated related to the provenances of third and fourth groups only after 15 years. Fir provenance Bosanski Petrovac shows better growth than fir provenances from the second group only after the $20^{\text {th }}$ year. Provenances from the second group from the $10^{\text {th }}$ year of age are separating from the third and fourth group by better growth. In growth fir provenances that belong to the third and fourth group have no larger differences. Graph 2 shows the curve of height increment of fir provenances determined by Duncan groups by characteristic of mean height (1-4). Graph makes it visible that the culmination of height increment of different provenances of fir appeared between 20 and 25 years of age. All fir provenances had height increment culmination in approximately the same age, but the current height increment had different values in specific groups. Analog to the height, the height increment in fir provenance from Bosanski Petrovac during its entire growth has had the highest values, and those are particularly highlighted in period of height increment culmination. The lowest height increment was in the fir provenances of the third and fourth Duncan group. Having in mind the flow of the curve of height increment of four fir provenances it is possible to conclude that even in the later stages of growth there will be no significant oscillations in the intensity of growth of provenances. It is to expect that Bosanski Petrovac's provenance in further will have the best growth and increment.

\section{Tree volume}

Based on measured diameters and heights for each tree, according to NAGEL, (1988) its average volume per one tree. Results of the examination of characteristic "average tree volume" are provided in Table 5. From the table, we can see that the largest average tree volume is in the provenance Bosanski Petrovac $\left(0.061 \mathrm{~m}^{3}\right)$. Then follows provenances Fojnica and Sokolac with $0.051 \mathrm{~m}^{3}$. Somewhat smaller tree volume is in provenances Prozor, Olovo-Palež, Bugojno, Pale, Olovo-Klis that is in the range from 0.470 to $0.450 \mathrm{~m}^{3}$. Provenance Konjic has the smallest average tree volume $\left(0.043 \mathrm{~m}^{3}\right)$. Analysis of variance showed that there are statistically significant differences in the level of statistical significance of $95 \%$ for the examined characteristic "average tree volume". 
Table 5. Average tree volume of 9 Bosnian-Herzegovinian fir provenances on experimental plot/area Delimusa

Tabela 5. Prosječna zapremina stabla 9 bosanskohercegovačkih provenijencija jele na ekperimentalnoj površini Delimusa

\begin{tabular}{|c|c|c|c|c|c|c|c|c|}
\hline \multirow{2}{*}{ No. } & \multirow{2}{*}{ Provenance } & \multirow{2}{*}{$\mathrm{N}$} & \multirow{2}{*}{$\begin{array}{c}\mathrm{V} \text { of the tree } \\
\left(\mathrm{m}^{3}\right)\end{array}$} & \multirow{2}{*}{ Std } & \multirow{2}{*}{$\mathrm{CV} \%$} & \multicolumn{3}{|c|}{ Duncan group } \\
\hline & & & & & & 1 & 2 & 3 \\
\hline 1. & Bos. Petrovac & 218 & 0.06185 & \pm 0.04161 & 67.28 & \multirow[t]{9}{*}{$*$} & \multirow{9}{*}{$\begin{array}{l}* \\
* \\
* \\
* \\
*\end{array}$} & \multirow[b]{4}{*}{ * } \\
\hline 2. & Fojnica & 271 & 0.05164 & \pm 0.03482 & 67.42 & & & \\
\hline 3. & Sokolac & 243 & 0.05107 & \pm 0.03417 & 66.92 & & & \\
\hline 4. & Prozor & 246 & 0.04711 & \pm 0.03238 & 68.73 & & & \\
\hline 5. & Olovo-Palež & 256 & 0.04638 & \pm 0.03315 & 71.49 & & & \multirow{2}{*}{$\begin{array}{l}* \\
\text { * }\end{array}$} \\
\hline 6. & Bugojno & 194 & 0.04615 & \pm 0.03132 & 67.86 & & & \\
\hline 7. & Pale & 228 & 0.04564 & \pm 0.03336 & 73.10 & & & * \\
\hline 8. & Olovo-Klis & 202 & 0.04560 & \pm 0.02545 & 55.81 & & & * \\
\hline 9. & Konjic & 240 & 0.04342 & \pm 0.02856 & 65.77 & & & * \\
\hline \multicolumn{5}{|c|}{$\mathrm{F}=5.845$} & \multicolumn{3}{|c|}{ Sig. 0.005} & \\
\hline
\end{tabular}

In order to determine statistical differences between fir provenances, we conducted the Duncan test. Results of the test showed grouping of fir provenances, as per examined characteristic "average tree volume", into three Duncan groups. In the first group with the largest average tree volume is provenance Bosanski Petrovac. This provenance in terms of average tree volume is statistically significantly different than the other provenances. The second group, with lower average tree volume, includes provenances Fojnica, Sokolac, Prozor, Olovo-Palež, Bugojno Pale and Olovo-Klis. The third group, with the lowest average tree volume, includes provenances Prozor, OlovoPalež, Bugojno, Pale, Olovo-Klis and Konjic. Provenance Konjic, that is in the third group, is statistically significantly different than provenances of the first and the second Duncan group as per the lowest average tree volume. Provenances from the second Duncan group Fojnica and Sokolac as per larger average tree volume are different than all provenances of the third Duncan group (Table 5). The coefficient of variability $(\mathrm{CV} \%)$ for characteristic average tree volume is in a range from 55 to $73 \%$.

\section{DISCUSSION - Diskusija}

In the 70 s of the past century, due to noticeable degradation of fir caused by effects of damaging agents, intensified the works on setting-up of provenance experiments with the fir (WOLF, 2003). In many countries of Europe, experiments were established with silver fir provenances from all areas of its natural distribution (LARSEN, 1986, KRAMER and STEPHAN 1992, MEKIĆ, 1991, HALILOVIĆ et al. 2013, KERR, 2015, STOJNIĆ et al. 2016.). Lately, we are faced with new challenges in the form of climate changes that can lead to dying-out of specific native tree species, even fir. Up-to-date research in Austria and Germany has shown that the silver fir, unlike spruce, is more resilient to drought and it shows significantly better adaptability and plasticity (ROTHE et al. 2011). Actual studies from Switzerland show that large 
complexes of spruce forests, according to forecasted scenarios of climate changes, shall disappear and that their place can be replaced by the silver fir, exactly due to its adaptability to increased temperatures and drought (FRANK et al. 2017). In his work KERR, (2015) concludes that fir is a very adaptable and productive tree species that can be used outside its natural areal with the objective to raise mixed forests resilient to climate changes, pests and diseases. These statements show that we have to establish new, and monitor old provenance trials with silver fir, and find resilient, adaptable and fast-growing populations that can be used for afforestation on local and global levels. These researches also showed that examined Bosnian-Herzegovinian provenances of silver fir are vital, resilient and adaptable to habitat conditions that rule on the location of "Delimusa".

Table 6: Growth of heights in specific age classes of researched fir provenances in $14^{\text {th }}, 20$ th (HALILOVIĆ and others 2013) and $28^{\text {th }}$ year of age

Tabela 6: Razvoj visina u pojedinim starosnim klasama istraživanih provenijencija jele u 14.-oj, 20.-oj (HALILOVIĆ i dr. 2013) i 28-oj godini starosti

\begin{tabular}{|c|c|c|c|c|c|c|c|c|c|c|c|c|c|}
\hline Rang & Provenance & H (m) 14 & \multicolumn{2}{|c|}{$\begin{array}{c}\text { Duncan } \\
\text { group }\end{array}$} & Provenance & $\mathrm{H}(\mathrm{m}) 20$ & \multicolumn{2}{|c|}{$\begin{array}{c}\text { Duncan } \\
\text { group }\end{array}$} & Provenance & $\mathrm{H}(\mathrm{m}) 28$ & \multicolumn{3}{|c|}{ Duncan group } \\
\hline 1. & B. Petrovac & 1.71 & $*$ & & B. Petrovac & 4.07 & $*$ & & B. Petrovac & 9.1 & $*$ & & \\
\hline 2. & Konjic & 1.68 & $*$ & & Fojnica & 3.99 & $*$ & & Sokolac & 8.7 & * & & \\
\hline 3. & Prozor & 1.68 & $*$ & & Bugojno & 3.89 & * & $*$ & Fojnica & 8.6 & * & & \\
\hline 4. & Fojnica & 1.67 & $*$ & $*$ & Sokolac & 3.88 & $*$ & $*$ & Prozor & 8.3 & $*$ & $*$ & \\
\hline 5. & Bugojno & 1.67 & $*$ & $*$ & Prozor & 3.87 & $*$ & $*$ & Olovo-Palež & 8.2 & $*$ & $*$ & * \\
\hline 6. & Sokolac & 1.64 & $*$ & $*$ & Konjic & 3.83 & $*$ & $*$ & Bugojno & 8.2 & & $*$ & * \\
\hline 7. & Olovo-Palež & 1.63 & $*$ & $*$ & Olovo-Palež & 3.76 & & $*$ & Konjic & 8.1 & & $*$ & * \\
\hline 8. & Pale & 1.57 & & $*$ & Pale & 3.70 & & $*$ & Pale & 8.1 & & & * \\
\hline 9. & Olovo-Klis & 1.55 & & $*$ & Olovo-Klis & 3.64 & & $*$ & Olovo-Klis & 8.1 & & & $*$ \\
\hline & $\mathrm{F}=$ & $=2.55$ & & & & $F=3.24$ & & & & $\mathrm{~F}=6.12$ & & & \\
\hline
\end{tabular}

Table 6 shows a comparative analysis of mean heights of 9 fir provenances in $14^{\text {th }}, 20^{\text {th }}$ and $28^{\text {th }}$ year of age. It is visible from the table that provenance Bosanski Petrovac from the start shows the best growth. This provenance in its mean height is statistically significantly different than the other 8 provenances. Provenances with the smallest growth; Olovo-Klis and Pale, have the lowest mean height since the age of 14. Fir provenance Konjic in the $14^{\text {th }}$ year belonged to the provenance group with the best growth, while in the $28^{\text {th }}$ year of age it fell under group with the smallest growth. Vice 
versa, provenance Sokolac that at the age of 14 was in a group with the smallest growth in the $28^{\text {th }}$ year shows good growth.

If we analyse the mean height of provenances in the $28^{\text {th }}$ year of age it moves in all provenances in the range from 8.1 to $9.1 \mathrm{~m}$. SZELIGOWSKI et. al (2011) in their research with 5 Polish and one German provenance of fir in 30-years of the age of the trees, gained mean heights in a range from 5.4 to 7.8 meters. According to SCHOBER, (1979) mean height of fir of the first yield class, in 30-years of age, for the area of Central Europe amounts to $7.7 \mathrm{~m}$.In these researches mean heights in all researched Bosnian-Herzegovinian fir provenances in 28-years of age are larger than mean heights of 30-years of age firs as per tables of SCHOBER, (1979) and research of SZELIGOWSKI and others (2011). Better increment of South-European provenances of silver fir is confirmed by many researches (LARSEN, 1986; LARSEN and MEKIĆ 1991; MAYER et al. 1980; MEKIĆ, 1992; KAJBA, 2001; KERR, 2015).

Table 7. Mean diameter of 9 Bosnian-Herzegovinian fir provenances in $20^{\text {th }}$ year of age (HALILOVIĆ et al. (2013)) and $28^{\text {th }}$ year of age

Tabela 7. Srednji prečnik 9 bosanskohercegovačkih provenijencija jele u 20-oj godini (HALILOVIĆ i dr. (2013) i 28-oj godini starosti

\begin{tabular}{|c|c|c|c|c|c|c|c|c|}
\hline Rang & Provenance & $\mathrm{D}(\mathrm{cm}) 20$ & \multicolumn{2}{|c|}{$\begin{array}{c}\text { Duncan } \\
\text { group }\end{array}$} & Provenance & $\mathrm{D}(\mathrm{cm}) 28$ & \multicolumn{2}{|c|}{$\begin{array}{c}\text { Duncan } \\
\text { group }\end{array}$} \\
\hline 1. & Bos.Petrovac & 4.7 & \multirow{3}{*}{$\begin{array}{l}* \\
* \\
*\end{array}$} & \multirow{3}{*}{$\begin{array}{l}* \\
*\end{array}$} & Bos. Petrovac & 11.9 & \multirow[t]{9}{*}{$*$} & \\
\hline 2. & Fojnica & 4.63 & & & Fojnica & 11.2 & & * \\
\hline 3. & Konjic & 4.50 & & & Sokolac & 11.1 & & * \\
\hline 4. & Sokolac & 4.47 & \multirow{6}{*}{$\begin{array}{l}* \\
* \\
*\end{array}$} & * & Olovo-Klis & 11.1 & & * \\
\hline 5. & Bugojno & 4.45 & & * & Prozor & 10.9 & & * \\
\hline 6. & Prozor & 4.41 & & \multirow{2}{*}{$\begin{array}{l}* \\
*\end{array}$} & Pale & 10.8 & & * \\
\hline 7. & Olovo-Palež & 4.25 & & & Bugojno & 10.8 & & * \\
\hline 8. & Olovo-Klis & 4.17 & & \multirow[t]{2}{*}{$*$} & Olovo-Palež & 10.8 & & * \\
\hline 9. & Pale & 4.16 & & & Konjic & 10.7 & & * \\
\hline \multicolumn{5}{|c|}{$\mathrm{F}=2.19$} & \multicolumn{4}{|c|}{$F=6.12$} \\
\hline
\end{tabular}

From Table 6. We can see that growth of mean diameter in provenances of fir in the $20^{\text {th }}$ year of age and $28^{\text {th }}$ year of age. Provenance Fojnica in the $20^{\text {th }}$ year had a larger mean diameter while in the $28^{\text {th }}$ year the larger mean diameter was recorded in provenance Bosanski Petrovac. Provenance Konjic in the $20^{\text {th }}$ year belonged to the provenance group with the best mean diameter, and in the $28^{\text {th }}$ year, it would have the smallest mean diameter $(10.7 \mathrm{~cm})$. SZELIGOWSKI, (2011) determined the mean 
diameter of 6 tested provenances of fir of $6.2 \mathrm{~cm}$. According to yield tables of SCHOBER, (1979), fir in its best habitats in the $30^{\text {th }}$ year of age has a mean diameter of $8 \mathrm{~cm}$. Results of the research shows that $28^{\text {th }}$ year-old Bosnian-Herzegovinian silver fir provenances that have the smallest increment (Konjic, Olovo-Klis, Pale) have larger mean diameter, from the mean diameter of 30-year old silver fir of the first yield class for area of Central Europe according to SCHOBER, (1979), and Polish provenances of fir (SZELIGOWSKI, 2011).

From the results of the study, we can see that the smallest volume of the mean tree is in the provenance of $\left(0.043 \mathrm{~m}^{3}\right)$, while the largest volume was recorded in provenance Bosanski Petrovac with $0.062 \mathrm{~m}^{3}$. If the volume of the mean tree is calculated for hectare, then fir provenance Konjic has a volume of $90.09 \mathrm{~m}^{3} / \mathrm{ha}$, and provenance Bosanski Petrovac has a value of $111.33 \mathrm{~m}^{3} / \mathrm{ha}$. The difference in percentage between volume of mean tree in these two provenances is $29.8 \%$, while the difference in percentage in volume per hectare between provenances Konjic (smallest volume) and provenance Bosanski Petrovac (largest volume) is significantly smaller and amounts to $19 \%$. This appearance that difference in percentage between volume of mean trees of provenances Konjic and Bosanski Petrovac is significantly larger in relation to difference in percentage in volume of these provenances per hectare $(29.8 \%$ vol.trees $\mathrm{m}^{3}>19 \%$ vol. $\mathrm{m}^{3} / \mathrm{ha}$ ) can be explained with larger number of trees determined in provenance Konjic (2,075 trees/ha), related to Bosanski Petrovac (1,800 trees/ha), which finally influences on the total volume of assortment. In yield tables of SCHOBER, (1979) for the first yield class, the mean diameter of fir in 30 years of age amounts to $8.0 \mathrm{~cm}$, and mean height is $7 \mathrm{~m}$, which is below mean values of poorest ranked provenance in these researches. According to yield tables of SCHOBER, (1979) volume of fir assortment in 30 years of age amounts to $105 \mathrm{~m}^{3} / \mathrm{ha}$, but such large volume is influenced by a significantly larger number of fir trees per hectare $(6,320$ trees/ha).

Graphs 3. and 4. Depicts the influence of altitude and geographic position of assortment from which we collected seed material for the experiment. 


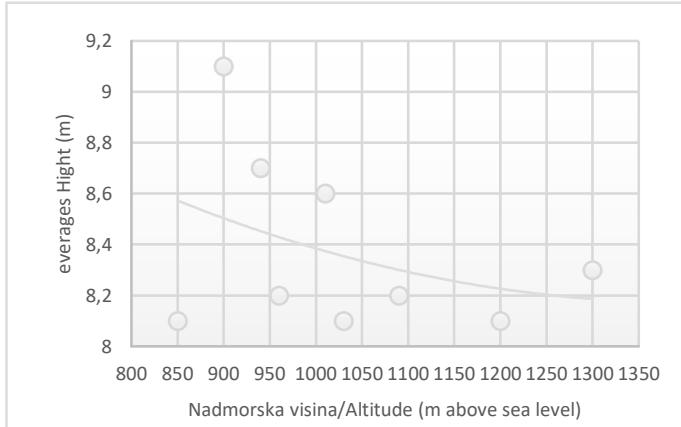

Graph 3. Growth in height of provenances depending on source origin of reproductive material

Grafikon 3. Razvoj visine provenijencija u zavsnosti od izvornog porijekla reproduktivnog materijala

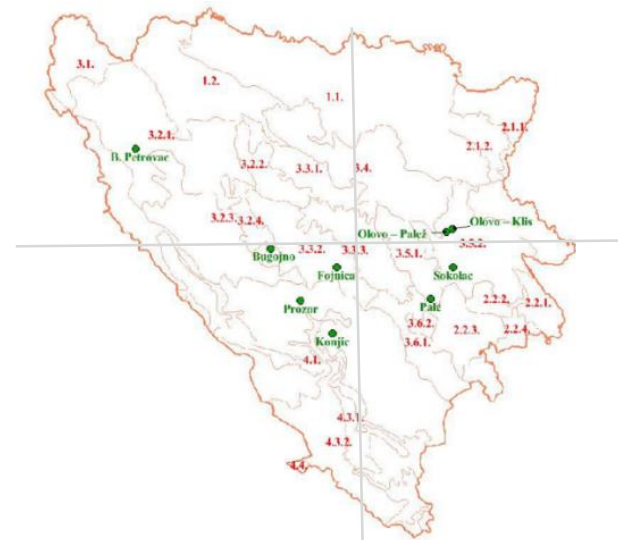

Graph 4. Geographic origin of researched fir provenances

Grafikon 4. Geografska pripadnost istraživanih provenijencija jele

Graphs make it possible to see that there is none correlating dependence between mean height of fir provenances and altitude of source origin of seed material of individual fir provenances. There is less expressed trend that fir provenances from lower altitudes have larger mean height, especially in fir whose source assortment is located on altitudes below 1,000 meters. Graph 4 shows the geographic position of source assortments of fir. Analysis determined that fir provenance from Western Bosnia has the largest values of mean diameter and mean heights, while local provenances Pale and Olovo-Klis showed the lowest values of mean height and mean diameter. Gained differences in growth between local provenances of fir could be explained by specific micro-climate and habitat conditions that are changing in a very small area. On larger inner-population variability of local Calabrian silver fir provenances, MEKIĆ, (1988) points out in his researches. STEFANOVIĆ, (1986) emphasizes that the area of Dinarides mountains is very specific in terms ofenvironmental conditions because in a very small area there are a large variety of climate, edaphic, orographic and other factors that impact on differentiation of various eco-types, and especially in the area of Central Bosnia. Because of that forest tree species from the Dinarides mountains show large variability compared to the same species from the north, therefore, on relatively small areas we could find large tree species variability (BALLIAN and ČABARAVDIĆ 2005, BALLIAN and HALILOVIĆ 2016). 


\section{CONCLUSION - Zaključak}

This paper researches morphological characteristics of 28-year old trees of nine provenances of silver fir on the experimental area "Delimusa" near Olovo.

Tested populations of fir are statistically significantly different in sense of height and mean diameter which can have large economic and ecological importance. Silver fir provenance from Bosanski Petrovac showed to be superior related to all other provenances. The mean height of this provenance of fir in 28 years of age amounts to $9.1 \mathrm{~m}$, while the mean breast height diameter is $11.9 \mathrm{~cm}$. Provenances that show the lowest growth $(8.1 \mathrm{~m})$ are Pale, Olovo-Klis and Konjic, while the silver fir provenance Konjic is with the smallest mean diameter $(10.7 \mathrm{~cm})$. In all provenances culminated increment in height in ages between 20 and 25 years. Variability of silver fir for examined characteristic "mean height" is larger (four population groups) compared to examined characteristic "mean diameter" of two population groups.

Calculated volume of mean tree $\left(0.062 \mathrm{~m}^{3}\right)$ and assortment $\left(111.33 \mathrm{~m}^{3} / \mathrm{ha}\right)$ in provenance Bosanski Petrovac is larger than silver fir volume for the first yield class in Central Europe. All 9 Bosnian-Herzegovinian fir provenances on the experimental area showed good adaptability, resilience, vitality and growth. Results of these researches open possibility of introduction of Bosnian-Herzegovinian silver fir into some areas of Central Europe whose ecological characteristics are suitable to biological characteristics of the silver fir, and in which individual tree types are currently endangered by climate changes.

Variability in growth of 9 Bosnian-Herzegovinian fir provenances developed as a consequence of specific climate and orographic - edaphic conditions in $\mathrm{B} \& \mathrm{H}$, which are changing/alternatingon very small area creating ecological niche suitable for differentiation of silver fir.

\section{REFERENCES - Literatura}

BADEA,O., TANASE, M., GEORGETA, J., ANISOARA, L., PEIOV, A., UHLIROVA, H., PAJTIK, J., WAWRZONIAK, J., SHPARYK, J.(2004): Forest health status in the Carpathian Mountains over the period 1997-2001. Environmental Pollution 130:93-98.

BALIĆ, B., MEŠKOVIĆ, E. (2003): DAS - dendrometrijska analiza stabla, Softver za dendrometrijsku analizu stabla.

BALLIAN,D., ČABARAVDIĆ, A. (2005): Međupopulacijska varijabilnost nekih morfoloških svojstava obične jele (Abies alba Mill.) iz središnje Bosne. Radovi Šumarskog instituta 40 (1) :5-18, Jastrebarsko.

BALLIAN,D.,HALILOVIĆ,V. (2016): Varijabilnost obične jele (Abies alba Mill.) u Bosni i Hercegovini, Udruženje inžinjera i tehničara šumarstva Federacije Bosne i Hercegovine i Silva Slovenica, Sarajevo, Ljubljana. 
BARBU, I. (1991): Moarte abradului-simptomal degradarii mediului. Ed.Cerec Bucuresti, Romania, str.1-276.

BECKER, A. (1971): Ökologische Varianzder Weisstanne und wald bauliche Folgerungen. Allg. Forstztg., 26 (49) : 1011.

DUCCI, F. (1991): Morphological variation in silver fir (Abies alba Mill.) seedlings from provenances in central and southern Italy. Annali del' Instituto Sperimentale per la Selvicoltura, publ. 1944, 22:53-73.

ELLING, W. (1993): Immisionim Ursachen komplex von Tannen schaaund Tannen sterben. Allg. Forst-Zeitschrift, 48:87-95.

ELLING, W., BRETSCHNEIDER, M., SCHWARZFISCHER, C. (1999): Zuwachs depressionan Tanne durch Schwefel-Emissionen. Allg.Forst-Zeitschrift, 54:896898.

ENGLER, A. (1905): Ein fluss der Prevenienz des Samensauf die Eigenschaft end er forsticher Gewächsen. Mitt. Schweiz. Anst. forstl. Versuchswes., 8:81-235.

FILIPIAK, M., NAPIERATA-FILIPIAKA. (2009): Effect of canopy density on the defoliation of the European silver fir (Abies alba Mill.) due to heavy industrial pollution. Dendrobiology, 62:17-22.

FRANK, A. HOWE, G.T., SPERISEN, C. BRANG, P. CLAIR, J.B.S. SCHMATZ, D.R. HEIRI, C. (2017): Risk of genetic maladaptation due to climate change in three major European tree species. Glob Chang Biol. 2017 Dec; 23 (12):5358-5371. doi: 10.1111/gcb.13802. Epub 2017 Aug 10.

HALILOVIĆ, V., BALLIAN, D., MEKIĆ, F., VIŠNJIĆ, Ć. (2009a): Morphological analysis of some assimilation characteristics of the silver fir (Abies alba Mill.) in the experiment Delimusa. Works of the Faculty of Forestry Univesity of Sarajevo, No 2. (15-25).

HALILOVIĆ, V., MEKIĆ, F., VIŠNJIĆ, Ć., BALLIAN, D. (2009b): Varijabilnost visinskog prirasta devet provenijencija obične jele (Abies alba Mill.) iz $\mathrm{BiH}$ u pokusu „Delimusa“ kod Olova. Naše šume - Časopis za unapređenje šumarstva, hortikulture i očuvanja okoline, Sarajevo, No. 14-15, godina VIII, str. 11-19.

HALILOVIĆ, V., MEKIĆ, F., VIŠNJIĆ, Ć., BALLIAN, D. (2013): Variability of some morphological features of silver fir (Abies alba Mill.) in a national test of proveniences. Works of the Faculty of Forestry University of Sarajevo, No. 1, 2013 (55-65).

KAJBA, D. (2001): Unutar populacijska i među populacijska varijabilnost obične jele. Obična jela u Hrvatskoj, Zagreb, Str. 322-345.

KERR, G., STOKES, V., PEACE, A., JINKS, R. (2015): Effects of provenance on the survival, growth and stem form of European silver fir (Abies alba Mill.) in Britain. Eur J Forest Res. 134:349-363. 
KOBLIHA, J., STEJSKAL, J., ŠKORPIK, P., FRAMPTON, J. (2013a): Recent results of Czech-American fir hybridization research. Journal of Forest Science, 59 (2):6471.

KOBLIHA, J., STEJSKAL, J., LSTIBUREK, M., TYPTA, J., TOMAŠKOVA, I., JAKUBUV, P. (2013b): Testing of hybrid progenies and various species of genus abies for forestry, decorating horticulture and Christmass tree production. Acta Scientiarum Polonorum-Hortorum Cultus, 12 (4): 85-94.

KORMUTAK, A., VOOKOVA, B., ČAMEK, V., SALAJ, T., GALGOCI, M., MANKA, P., BOLEČEK, P., KUNA, R., KOBLIHA, J., LUKAČIK, I., GOMORY, D. (2013): Artificial hybridization of some Abies species. Plant Systematics and Evolution, 299 (6):1175-1184.

KRAMER,W., STEPHAN, B.R. (1992): Zur Entwicklung von Herkünf tender Weißtanne (Abies alba Mill.) in Nordwest deutschland, 6IUFRO Tannen symposium, Zagreb,15-23.

LARSEN, J.B. (1986): Geography variation in silver fir (Abies alba Mill.) growth rate and frost resistance. Fortwissenschaflitches Centralblatt, Gottingen, 105:396-406.

LARSEN, J.B., FRIDRICH, J. (1988): Growth reactions of diferent provenances of silver fir (Abies alba Mill.) after SO2 fumigation during the winter, European Journal of Forest Patology, 18 (3-4): 190-199.

MAYER, H., REIMOSER, E., KRAL, F. (1980): Results of the international fir provenance trial, Wien, 1967/78, Growth and morphology of the provenances, Centralblat fur das gesamte Fortswesen, 99 (3):169-191.

MEKIĆ, F., LARSEN J. B. (1991): The geographic variation in European silver fir (Abies alba Mill.) gas exchange and needle cast in relation to needle age, growth rate, dry matter partitioning and wood density by 15 different provenances at age 6 , Silvae Genetica, 40 (5-6):118-198.

MEKIĆ, F. (1988): Gas wechsel physiologische und morfologische Unter suchungenan 5-6 jaehrigenWeisstannen-Provenienze (Abies alba Mill.). Dissertation, Institut für Waldbauder Univerzität Göttingen, 1-144.

MEKIĆ, F. (1991): Morfološke karakteristike petogodišnjih sadnica jele (Abies alba Mill.) sa devet lokaliteta u BiH. Univerzitet u Beogradu, Glasnik Šumarskog fakulteta, Beograd br.73.str. 141-152.

PINTARIĆ, K. (2002): Šumsko-uzgojna svojstva i život važnijih vrsta šumskog drveća. Sarajevo: Udruženje šumarskih inžinjera i tehničara Federacije Bosne i Hercegovine. str.221.

ROTHE A., DITTMAR C. i ZANG C. (2011): Tanne - vom Sorgen kind zum Hoffnung sträger. LWF Wissen 66: 59-63.

SCHOBER R. (1979): Ertragstafeln wichtiger Baumarten. J.D. Sauerlaenders Verlag, Frankfurt a.M. str. 154. 
STEFANOVIĆ, V. (1977): Fitocenologija sa pregledom šumskih fitocenoza Jugoslavije, Zavod za udžbenike, Sarajevo, Str.1-269.

STEFANOVIĆ, V., BEUS, V., BURLICA, Č., DIZDAREVIĆ, H., VUKOREP, I. (1983): Ekološko-vegetacijska rejonizacija Bosne i Hercegovine. Radovi Šum.fakulteta i Instituta za šumarstvo, Posebno izdanje No 17, Sarajevo, 51 str.

STOJNIĆ, S., ORLOVIĆ, S., TRUDIĆ, B., KESIĆ, L., STANKOVIĆ, M., ŠIJAČIĆNIKOLIĆ, M. (2016): Varijabilnost visina i prečnika sadnica različitih provenijencija bukve poreklom iz jugoistočne Evrope. Topola br. 197-198, str 514.

SZELIGOWSKI, H., BOLIBOK, L., BURACZYK, W., DROZDOWSKI, S. (2011): Analiza wybrany chcech jod ${ }^{3} y$ pospolitej (Abies alba Mill.) napowierzchni proweniencyjnej w Rogowie. Leœne Prace Badawcze (Forest Research Papers), 2011, Vol. 72 (3): 225-231.

UŠČUPLIĆ, M. (1992): Uticaj sistema gazdovanja na pojavu imele (Viscum album L.). Glasnik Šmarskog fakulteta u Beogradu, Str.7-18.

UŠČUPLIĆ, M., DAUTBAŠIĆ, M., TREŠTIĆ, T., NIŠIĆ, T., JOKANOVIĆ, B., SELMAN, E., MUJEZINOVIĆ, O. (2007): Bolesti i štetnici obične jele (Abies alba Mill.) u Bosni i Hercegovini. Društvo za zaštitu bilja u Bosni i Hercegovini, 1-114, Sarajevo.

WENTZEL, K.F. (1980): Weisstane=immission sempfind-lichsteheimische Baumart. Allg. Forst-Zeitschrift, 35:373-374.

WOLF, H. (2003): EUFORGEN Technical Guidelines for genetic conservation and use for silverfir (Abies alba Mill.). International Plant Genetic Resources Institute, Roma, Italy. 6 pages. 


\section{SAŽETAK}

U ovom radu istraživan je rast devet provenijencija jele iz područja njenog prirodnog rasprostranjenja u Bosni i Hercegovini. Eksperiment je postavljen 1991. godine u obliku slučajnog blok sistema sa 5 ponavljanja. Za sadnju su korištene petogodišnje sadnice jele (2/3) a razmak sadnje je bio $2 \times 2 \mathrm{~m}$. Svaka provenijencija jele je bila zastupljena sa 320 biljaka. Rezultati mjerenja u 28-oj godini starosti pokazuju postojanje varijabilnosti između provenijencija jele u obilježjima; srednja visina, srednji prečnik i prosječna zapremina stabla. Provenijencija jele iz Bosanskog Petrovca je pokazala najbolje rezultate. Srednja visina ove provenijencije jele u starosti od 28 godina iznosi $9,1 \mathrm{~m}$, dok je srednji prečnik $11,9 \mathrm{~cm}$. Provenijencije koje pokazuju najslabiji rast $(8,1 \mathrm{~m}) \mathrm{su}$ Pale, Olovo-Klis i Konjic. Provenijencija jele Konjic ima najmanji srednji prečnik (10,7 $\mathrm{cm}$ ). Kod svih provenijencija je kulminirao prirast u visinu u starosti između 20 i 25 godina. Varijabilnost između testiranih provenijencija jele za ispitivano obilježje "srednja visina" je veća (četiri skupine populacija) u odnosu na ispitivano obilježje "srednji prečnik" (dvije skupine populacija). Zapremina srednjeg stabla $\left(0,062 \mathrm{~m}^{3}\right)$ i sastojine $\left(111,33 \mathrm{~m}^{3} / \mathrm{ha}\right)$ kod provenijencije Bosanski Petrovac je veća od tabličnih vrijednosti za prvu prinosnu klasu za uvjete srednje Evrope.

Varijabilnost u rastu 9 bosansko-hercegovačkih provenijencija se razvila zbog specifičnih klimatskih i orografsko edafskih uvjeta koji vladaju u $\mathrm{BiH}$, i smjenjuju se na vrlo malom prostoru stvarajući ekološke niše pogodne za diferencijaciju jele.

Rezultati ovih istraživanja otvaraju mogućnost introdukcije bosanskohercegovačke jele u neka područja srednje Evrope kao i šire van njenog prirodnog areala, gdje stanišne karakteristike odgovaraju biološkim svojstvima jele, a u kojim su pojedine vrste drveća trenutno ugrožene klimatskim promjenama.

Corresponding author: Ćemal Višnjić, Faculty of Forestry University of Sarajevo; Zagrebačka 20, 71000 Sarajevo, Bosnia and Herzegovina; e-mail address: c.visnjic@sfsa.unsa.ba 